\title{
"The inconvenience of the present arrangement can only be realized by those who have to work under it": a History of the Legal Research Collections at McGill.
}

\author{
by A.J. Hobbins
}

\begin{abstract}
The origins of McGill University's Faculty of Law and of its law library stretch back to the 1840s. With the formal establishment of the Faculty in 1853, the issue of books and a library became acute. Through donations from a variety of benefactors a respectable collection of books began emerging. Only with Sir William Macdonald's endowment for the Faculty in 1890, however, was ongoing support for the library finally guaranteed. Like the Faculty, the law library moved about considerably until 1949 when both settled into the James Ross property at the north-west corner of Penfield and Peel. Even here, the library has been housed in various locations before moving in 1998 to the Nabum Gelber Law Library.
\end{abstract}

\section{RESUMÉ}

Les origines de la Faculté de droit de l'Université McGill et de sa Bibliothèque de droit remontent aux années 1840. Suite à la création formelle de la Faculté en1853, la question d'une bibliothèque et d'une collection de livres est devenue pressante. Grâce aux dons de divers bienfaiteurs, une collection respectable de livres commença à être établie. Ce n'est toutefois qu'avec la dotation que Sir William Macdonald fit à la Faculté en 1890 qu'un appui financier à long terme fut enfin garanti pour la Bibliothèque. Comme la Faculté, la Bibliothèque de droit s'est vu domiciliée à divers endroits jusqu’à 1949, quand la Faculté et la Bibliothèque se sont installées sur la propriété James Ross au coin nord-ouest des rues Penfield et Peel. Même après cette relocalisation, la Bibliothèque a occupé divers espaces jusquả ce qu'elle déménage en 1998 à la Bibliothèque de droit Nahum Gelber.

$\mathrm{L}$ aw professors and students at McGill University have often said that nothing is more important to them than the library. This view is generally held in legal academic circles. In 1956, bemoaning the state of Canadian law libraries, the Canadian Bar Association stated:

The facilities for research in Canada are inadequate. This is evident in the lack of proper libraries, of research funds and endowments and research centres and institutes whether within or without the law school. No researcher can work without proper equipment and the principal equipment for most types of legal research is good libraries. ${ }^{1}$

Current surveys indicate a high degree of satisfaction with the library resources-collections, services and study space-but this was certainly not always the case. ${ }^{2}$ The first library dedicated specifically to law was created in 1950, but law had been taught at McGill for more than a century before that. The legal resources available to McGill scholars have had a varied past that will be traced in this article.

\section{Founding of the Faculty}

William Badgley (1801-1888), a prominent Montreal lawyer, was appointed lecturer in law in April, 1844 under the aegis of the recently founded Faculty of Arts. ${ }^{3}$ The first law degrees were awarded in 1850. Up to this point there were no academic or professional requirements to practice law in Lower Canada, but this changed when the Bar was incorporated in $1849 .{ }^{4}$ The Act required all practicing lawyers to be members in good standing. While existing lawyers were grandfathered in, all new applicants had to pass the Bar examination. Qualification to sit the examination was five years articling for a practicing advocate, four years articling if the candidate had graduated from a college or seminary, or three years articling if the candidate followed a law course. On December, 1852 Laval University was incorporated by Royal Charter, and included a law faculty which at the time had no professors or students. ${ }^{5} \mathrm{McG}$ ill created its Law Faculty the following Spring, ${ }^{6}$ and transferred the students already studying law. ${ }^{7}$ Shortly thereafter the Bar Act was amended to allow those with a university or college degree from a law faculty to sit the examinations after three years of 
articling, and articling could be done simultaneously with the course of study. ${ }^{8}$

Badgley was appointed professor and later Dean in 1853. He was also given two colleagues to help with the teaching load-his business partner John J.C. Abbott (BCL 1854, DCL 1867) and Frederick Torrance (BCL 1865). ${ }^{9}$ They each received $£ 500$ from the University plus income from student fees. Nevertheless, they were all part-time and their main income came from continuing practice. Thus, unlike other disciplines, law was not taught on campus because students and faculty spent their days near the law offices downtown and the University was too far away. Classes were given in the evening in rented spaces in somewhat peripatetic fashion. ${ }^{10}$ Classes were originally given in Badgley's law office, but moved to the boardroom of Molson's Bank in 1854. In 1860, law courses were given in Burnside Hall at the corner of University Street and Dorchester Boulevard (now René Levesque) sharing tenancy with the High School of Montreal. ${ }^{11}$ When Burnside Hall was sold to the Protestant Board of School Commissioners in 1870, classes were moved back to Molson's Bank. They returned to Burnside Hall after it had been purchased by the Fraser Institute in 1890. By then plans were in place to create an on-campus Faculty with two full-time academic professors, and in 1896 this move was accomplished..$^{12}$ Initially housed in the East wing of the Arts Building, the Faculty continued to move going to 3484 University Street (1916), back to the East Wing (1922), up to share Purvis Hall with the School of Commerce (1942), before finally acquiring a more permanent home in the Ross Mansion, renamed Chancellor Day Hall (1949). ${ }^{13}$

\section{The University Library}

The University Library (then called the College Library) began as a reading room in the William Molson Hall under the control of an Honorary Librarian. ${ }^{14}$ The collection was made up almost entirely of donations, as was the case for most of the nineteenth century. A number of these donations, and three in particular, were important for the study of law. Frederick Griffin (1798-1877), a local lawyer and book collector, had been counsel to the Board of the Royal Institution during John Bethune's principalship as well as solicitor to the Bank of Montreal. He left his important collection to the University, although only a small portion was devoted to law. ${ }^{15}$ Charles Dewey Day (1806-1884) had been McGill Principal (1853-1855) and Chancellor (18641884). ${ }^{16}$ Between 1859 and 1865 he, with Augustin-Norbert Morin and René-Édouard Caron, drafted Quebec's first civil code. His collection was added to the library in 1885 . Finally, towards the end of his life, Judge Robert Mackay (18161888), who had already given his valuable art collection to the Fraser Institute, began donating his book collection to McGill University. ${ }^{17}$ The collection consisted of some 2,000 titles, of which 450 were on non-law subjects, and may at this time have represented $10 \%$ of the total University book holdings. ${ }^{18}$ All these materials were moved to the Redpath Library when this facility was opened in 1893.

\section{The Torrance Collection}

Although the University was building a decent law collection, it was not a great deal of use to the law students. Since they were required to article during the day and take courses near the law courts at night, there was little time to visit the campus. In the beginning they had to rely on the resources available in whichever office they were articling. In 1856, to alleviate the situation the Board of Governors:

Resolved that the President of the Board [i.e. Charles Dewey Day, President of the Royal Institution Board] be authorized to enter if possible into arrangements with the Advocates' Library and with the Section of the Bar for the District of Montreal, for the admission of the Students of the Faculty of Law to the Libraries of those Corporations. ${ }^{19}$

It was not until the late 1880 s, when they had access to collections of the Fraser Institute and, in particular, the Torrance Collection that the situation improved. In 1870 prominent Montreal merchant Hugh Fraser died, leaving the bulk of his estate to John J. C. Abbott and F.W. Torrance, as universal legatees, to do a project he had long discussed with Abbott. His money was to establish in Montreal "an institution to be called the Fraser Institute, to be composed of a free public library, museum and gallery, to be open to all honest and respectable persons whomsoever of every rank in life without distinction, without fee or reward of any kind....20 The Institute was to be modeled on the Institut Canadien that performed a similar service in the French community. A great deal of litigation followed, particularly from Fraser's brother John, and the matter was not settled for over a decade. ${ }^{21}$ Abbott, then a prominent commercial lawyer and Torrance, recently named a Judge of the Quebec Superior Court, were both also McGill professors at this time, with Abbott being Dean. ${ }^{22}$ When the litigation finally ended, the Institute's governors began to create the reality, purchasing Burnside Hall in $18844^{23}$ The Institute library was able to open in October, 1885 having acquired the collection of the Mercantile Library Associate, while that of the Institut Canadien came initially on loan. ${ }^{24}$ Torrance died in 1887 leaving his law library of over 4,000 books and 1,000 legal pamphlets to the Institute. ${ }^{25}$ This was the largest collection of legal materials in the province after the Advocates' Library, and became the more or less exclusive domain of the law students and professors when the Faculty moved to Burnside Hall in 1890. 


\section{The Macdonald Endowment}

It was also in 1890 that the nature and entire future of the Faculty was fundamentally changed. In response to ongoing problems of the faculty, Sir William Macdonald (then plain William McDonald, Esq.) gave the "largest benefaction hitherto received by this University". While he had previously given some modest amounts, Macdonald donated \$150,000 to the Law Faculty for the "extension and improvement of its work. ${ }^{26}$ This endowment created a chair for the position of Dean as a full-time academic, as well as a second full-time chair for the Faculty Secretary. Macdonald also specified that "The remainder of the income shall be devoted to the maintenance and improvement of the work of the Faculty in such manner as may be from time to time determined by the Board of Governors." Norman William Trenholme (18371919), who had been part-time dean, was given that position on a full-time basis. ${ }^{27}$ Archibald McGoun (1853-1921) was hired to the second chair as Professor of Legal Bibliography, Librarian and Faculty Secretary. ${ }^{28} \mathrm{He}$ was given modest amounts to augment and update the resources available to students through the Torrance collection at Burnside Hall. The Macdonald endowment required the faculty to move on campus, but space had to be found to move Science and Applied Science (Engineering) out of the Arts Building. To achieve this Macdonald had the Macdonald Engineering and the Macdonald Physics buildings constructed, which took some time to complete. The Faculty remained in Burnside Hall until 1896, finally having access to an outstanding book collection.

\section{A Long Loan}

The Torrance Collection had been placed in the rooms rented by the McGill Faculty in Burnside Hall rather than in the Institute Library, and had been used more or less exclusively by the students and professors. The Faculty was extremely reluctant to lose this resource despite the availability of the MacKay Collection. Permission was therefore requested, and granted, to have the Torrance Collection removed to the Redpath Library on long loan. ${ }^{29}$ When Frederick Parker Walton was appointed Dean in 1897, he apparently secured a commitment from the University that the 1901 extension to Redpath Library would include a law reading room capable of housing 20,000 volumes and 80 seats. ${ }^{30}$ Thus the Faculty finally had a large law collection situated in one place, although it has been suggested this was not heavily used at first. $^{31}$

\section{The Faculty and the University Library}

The responsibility for the Law Reading Room in the Redpath Library was divided. The University Librarian was given overall responsibility for the collection and the library staff acquired, catalogued and serviced the materials. The Faculty selected new materials from a relatively small grant. Most of the materials purchased were continuations-law reports and journals-while relatively few monographic works were selected. This system appeared to work well enough under the Deanship of Walton (1897-1914) and the tenure of University Librarian Charles Gould (1892-1919). The Faculty Secretary, Archibald McGoun, acted as 'Librarian' (1890-1920). However, in the period following the First World War the relationship became more complex and difficult. The reasons can be briefly summed up as involving the faculty's ambitions, the physical location, staffing, budgets and a new cast of principal players.

In 1918, Dean Robert Warden Lee (1914-1921) instituted his controversial national program, aimed at creating one of the world's great law schools. ${ }^{32}$ Under this program students could get a civil law degree, a common law degree or both. An LLM program was instituted. Courses were also offered to non-law students interested in government and politics. Up to this point the Faculty's mission had been to train lawyers for practice in Quebec civil law, and library resources had been acquired accordingly. Materials would now be required to support common law teaching, as well as foreign, comparative and international law at the undergraduate and graduate student level. Graduates would be able to practice in jurisdictions other than Quebec, although the United States accepted Lee's program rather more readily than the other Canadian provinces. The program also created a dramatic, if temporary, increase in enrollment caused in part by the added offerings but principally because of the large number of returning veterans wishing to take up their deferred studies. This increase naturally placed some strain on available library study space.

When Lee left to take up the Chair in Romano-Dutch Law at Oxford University and McGoun retired, library issues were taken up by H.A. Smith. Smith was an excellent scholar, but was notoriously strong-willed and difficult to deal with. ${ }^{33}$ For this reason he was not appointed Dean but given the role of Vice Dean, responsible for internal faculty affairs, while the deanship was given to a part-time instructor, Justice R.A.E. Greenshields. Following Charles Gould's death, Gerhard Lomer served as University Librarian (1920-1947). Smith served on the Library Committee under the chairmanship of Casey Wood. Following one meeting he wrote to Wood summarizing his concerns about library service for the faculty, stating:

It is obvious this involves a corresponding development in the library. At present we are pretty well provided with books on the civil law, both the old French law and the modern jurisprudence of this Province. But on the English law side, which includes American books, we are extremely weak. To build up a really first class library we need a large sum for immediate purposes and a substantial endowment to keep us up to date. In this connection 
I should like to emphasise the importance of having a good collection of old books and of books bearing on the historical side of the law. Law and history have always been very closely allied, and we must have a library which will attract the scholar and the research student, as well as the man who merely desires a professional education.

Our books are housed in two rooms of the Redpath Library. From Dr. Lomer and his staff we have always received every possible assistance, but the inconvenience of the present arrangement can only be realized by those who have to work under it. ... If our teaching and writing is to be really of the first order it is essential that we should have our library under our own roof. ${ }^{34}$

Wood replied that he sympathized with the problems and would cooperate to the extent possible. ${ }^{35}$ Meanwhile the Library had its own difficulties with the law collection. On discovering a mutilated book, Lomer wrote stiffly to Smith that "If the mutilation of law books continues we may have to consider the question of restricting the access of students to the Law Library." ${ }^{36}$

Smith's concerns were evidently taken seriously and considered in the plans for the 1921 Redpath extension. The first item of the proposal stated:

Old Law Library Room to be cleared and books placed on the top floor of the Old Stack, access to which will be obtained by cutting a staircase through the floor of the present New Law Reading Room. This portion of the Stack to be separated from the rest by a grating. Additional table space to be provided in the New Law Reading Room, and current law periodicals to be moved to the southern side of the adjoining gallery over the Main Reading Room. ${ }^{37}$

Ten days later, Lomer provided statistics on the size of the law collection: in the Law Library proper, 4,826 volumes; in the Law Reading Room 2,177 volumes; uncatalogued 5,000 volumes (which would have included the Torrance Collection) - for a total of 12,003 volumes. He indicated the Faculty had received a budget of $\$ 1,000$ in each of the preceding five years, and had acquired an average of 225 volumes each year. ${ }^{38}$

In 1923 the Faculty moved back to the East Wing of the Arts Building and a law library was created on the top floor. The University Librarian remained responsible for the collection and services, and Frances W. Lee, a cousin of the previous dean, was hired as the librarian. Lomer made it clear that no changes in service hour or staffing could take place without his approval. ${ }^{39}$ Smith happily offered the services of the library to members of the Montreal Bar at such times as the Court House Library was closed. ${ }^{40}$ This reading room contained only a portion of the law books both because of limited size and the floor lacked the strength to support book stacks. The larger part of the collection was stored in various places because the Redpath Library was too overcrowded to keep it. ${ }^{41}$

By 1927, Smith had resigned and was replaced by Percy Elwood Corbett (B.A. 1914). ${ }^{42}$ Lomer wrote to Corbett about the storage problem, proposing an approach to the Board of Governors:

I am as anxious as the members of your Faculty are to have these volumes out of storage and readily accessible; and I feel that a definite memorandum on the lack of accommodation for the Law Library should be included in the Annual Report of the Faculty and should be otherwise brought to the attention of the Governors. ${ }^{43}$

The Faculty adopted a resolution on the question at its meeting of March 7, 1927 noting "Consequently, a great number of very valuable books have been stored from time to time wherever space was available, having been housed for the last year in a stable", and forwarded it to the Board. ${ }^{44}$ The books in the poor conditions of the stable were boxed and unavailable. At their meeting of April 4, 1927 the Governors sympathized and resolved that something should be done, but could think of no practical solution to the matter. ${ }^{45} \mathrm{~A}$ temporary solution came within a year when it was reported: "Many applications have been made for books formerly packed away in cases. These are once more available, having been placed on shelves in the principal's garage." ${ }^{36}$

By 1929 Lomer evidently had become a little tired of the problems created by the Law library, and the associated costs to the University Library. He wrote to Corbett complaining of the amount of work done for the Law library and suggested the time might be right for the Faculty to follow the model of the Medical Library, with its own budgets and staff. Failing that, he noted "Miss Lee, who is not overworked, should undertake the cataloguing" or the Faculty should make some budgetary provision for the work done by the Library Staff. Nothing seems to have come of this initiative.

When Principal Currie died in 1933 the stored law collection could no longer be kept in the garage of the Baumgarten mansion. After further temporary housing, a longer term solution was found. Lt. Col. Erskine Buchanan (B.C.L. 1921) wrote to Dean Corbett, enclosing plans of the Workman Building attic describing the "...proposed space to be allotted to the law books which are now stacked in the Dining Room of our present building" ${ }^{\prime 77}$ The attic was capable of holding 10,000 volumes, which brought all the stored materials together although the librarian complained of a low, sloping ceiling. 


\section{The Struggle for the Torrance Collection}

On Hallowe'en, 1929 the faculty received an unpleasant surprise, when the Fraser Institute Librarian, Pierre de Crèvecouer (1862-1930), wrote to Stuart LeMesurier, requesting the return of at least part of the Torrance Collection:

....[E]nclosed please find the list of books belonging to the Fraser Institute. I have marked a few volumes that we would be glad to keep in our library. I must see our president, Mr. E. Lafleur, about the others. I suppose he will wait until next meeting of the Board to decide the fate of these volumes.

Eugene Lafleur (1856-1930), considered one of the most outstanding advocates of his day, was a McGill graduate (B.A. 1877 and B.C.L. 1880) and a professor in the Law Faculty (1890-1921). Despite his name, the fluently bilingual Lafleur's mother tongue was English and he was raised a Protestant. ${ }^{48} \mathrm{He}$ served as President of the Fraser Institute from 1915-1930. Anxious to retain the collection, Dean Corbett requested a meeting to discuss the matter. The Fraser governors agreed, naming Lafleur, John Fair and J.W.A. Hickson to represent them. ${ }^{49}$ The McGill delegation consisted of Corbett, Lomer and LeMesurier.

Prior to the meeting Lomer asked LeMesurier to obtain a copy of the bequest. ${ }^{50}$ Lafleur provided them with a brief extract from will which stated:

"... I give and bequeath all my library of books, bound and unbound, to the "Fraser Institute" of Montreal, for the public purposes of such Institution. To have and to hold such bequest to said Fraser Institute in property forever." 51

At the meeting on January 16, 1930 Corbett proposed that McGill retain the Torrance Collection, but provide the Fraser Institute with runs of duplicate journals. The Governors agreed to "think it over".52 Following the meeting, LeMesurier again requested more information about the will from one of Lafleur's partners. The response stated:

As regards Judge Torrance's Will, Mr. Lafleur does not consider it necessary to obtain a full copy of the Will and has instructed me to go through the Will for any other references that there may be to the disposition of books or to the Fraser Institute..$^{53}$

Although Smith noted there were no further references to the books or the Fraser Institute, Lafleur's reluctance to provide a full copy of the will was not without future significance. Whatever Lafleur's final decision may have been, the matter was dropped when both he and De Crèvecouer died a few months later.

Again nothing was done following an inquiry about the books in 1934. Dean Corbett requested time to replace important volumes before returning the collection. ${ }^{54}$ It was not until May 1938 that Hickson, now Acting Chairman of the Board for the octogenarian President John Fair, requested the return of the books. ${ }^{55}$ Lomer reminded the Faculty library representative, F.R. Scott, of the request a few months later, writing:

I find no definitive conclusion has been reached regarding the Torrance collection of law books apparently deposited in this library on long loan. The Fraser Institute library has asked for their return but I understand the Dean wishes to make some effort to retain the books at McGill. ${ }^{56}$

Scott responded:

...our feeling is that before the books are removed from our library, thus leaving serious gaps on our shelves and only adding to the Fraser Institute Library what would be an almost useless collection of law books, we would like to discuss the possibility of continuing the present arrangement... ${ }^{57}$

Scott then wrote to the Fraser Librarian, Miss A.G. McDougall, stressing the importance of the collection to the Law Faculty but noting that the collection itself, without the law library purchases surrounding it, would be of little value to members of the public since the books were more than forty years old. He proposed, should the Fraser Board agree, that any members of the Institute could use the collection at McGill if it remained there. ${ }^{58}$ Hickson rejected this suggestion and McGill prepared to return the books. ${ }^{59}$

Scott, however, continued to argue, writing again to McDougall:

[I]ncidentally you may be interested to learn that the separation of these books from the McGill collection produces some odd results. For instance, Vol 1 of the Canadian Supreme Court reports belongs to you, whereas vols 2 to the current volume belong to us. Hence you will have a single lonely volume of the reports, while we have a broken set. The removal of the important sets of Locré and Marcadé creates a gap that we are obliged to fill, since these are reference works; I wonder whether you will have one inquiry in five years for these authors in the Fraser Institute? However, if the letter rather than the spirit of the law is to be followed I suppose there is no solution to this result. ${ }^{60}$

McDougall's response was not encouraging.

After thoroughly discussing once more the question of the Torrance law books, the Governors decided they could not do otherwise than abide by the decision reached by our late President, Mr. Eugene Lafleur when he took this matter up with $\mathrm{Mr}$. Corbett in 1930. 
I deeply regret all the trouble the removal of these books from your library must cause you and the Librarians in charge. ${ }^{61}$

Lomer made one last attempt by writing to the President, John Fair:

Though I feel that you may perhaps not wish to discuss the matter further, I have a strong conviction that, as the circumstances having materially altered since 1930, owing to the regretted closing of the Circulation department of the Fraser library, it is highly desirable that, in view of the present situation, the matter be re-opened with a view to ascertaining whether the books in question are not of more use at McGill, where they are available for your readers, than they would be if they were transferred to the Fraser Library, where a diminishing staff would have difficulty in handling them. I feel, moreover, that, as neither the late Mr. Eugene Lafleur nor Mr. Corbett is directly connected with the law Library at McGill, a solution of a situation eight years ago should not be binding at the present time and the chief question to be considered is where the books can be of most use. $^{62}$

When Hickson, who had always been uncompromising of the issue, became President in October 1939, he renewed his insistence. The collection was returned over the next few months.

The saga of the Torrance collection has a sad ending. All of Scott's thoughts about the utility of the collection to the general public and Lomer's concerns about the ability of the Fraser Institute to manage the collection were amply justified. It was not until 1950 that the books were catalogued and made accessible. As Scott predicted, usage of the collection that had not been updated for sixty years was minimal. When the Institute (now the Fraser-Hickson Institute following Hickson's death) sold Burnside Hall to developers in 1957 and planned its move to NDG, thought was given to getting rid of what was now considered a white elephant. George Campbell, who had been Hickson's lawyer, gave his opinion on the terms of Torrance's will:

The phraseology adopted by the late Mr. Justice Torrance, "to have and to hold such bequest... in property forever", is reproduced almost identically several time in the will... Perhaps, therefore, too much significance need not be attached to that form of words, which was evidently a clause de style of the drafting notary... Even if the terms of the Torrance will were violated, only the residuary legatee would be in a position to complain.

He concluded that, since McGill University was in fact the residuary legatee, it would not be in a position to complain if the collection was offered back. ${ }^{63}$ The Governors adopted this view. Edgar Moodey commented on Campbell's advice, noting: "One can understand Eugene Lafleur's failure to raise this point, but it is a little mystifying that, in the past, it had escaped the ingenuity of the law faculty of the university."64 Perhaps Moodey would have been less mystified had he known Lafleur declined to provide the complete will to the professors, and they were unaware of repetitive language or the fact McGill was the residual legatee. Furthermore, the action was solicited nearly twenty years earlier when the collection had significant value.

The law librarian was asked to view the collection:

....all the Torrance collection was returned to the University: I recall going to Morrice Hall in 1958, sorting out books and making a selection of what we wanted to add back to the collection. The remainder was given to the University of Montreal. ${ }^{65}$

One cannot help but feel Torrance might have wished the saga had unfolded differently.

\section{Purvis Hall}

J.W. McConnell purchased and donated Purvis Hall to the University in 1941 and, in the following year, the Faculty of Law and the School of Commerce were located there. The main floor was converted to a reading room while book stacks were placed in the basement. ${ }^{66}$ This represented the first time the law collections were gathered together in one building, albeit sharing the space with the Commerce Library. ${ }^{67}$

\section{Chancellor Day Hall}

After eight years in Purvis Hall the Faculty moved into the James Ross mansion, another J.W. McConnell gift, which was renamed Chancellor Day Hall. Dean Sydney Bruneau reported enthusiastically on "...the ample classroom and library accommodation...." ${ }^{68}$ For the first time the faculty had its library, now numbering some 16,000 volumes, in unshared quarters under one roof. The library had sufficient staff to take over its own technical services, and collection funding was adequate. However, not all the collection could be placed in the reading room and many books were still stored in basement stacks and professors' offices. Although it had taken sixty years to reach 16,000 volumes, over the next fifteen years another 23,000 volumes were added. ${ }^{69}$ Thus, as in times past, the main problem was always space.

In 1967 a new building was erected, named New Chancellor Day Hall, in which the top four floors were devoted to the Law Library. The Faculty started the National Programme the following year and common law was again taught, requiring library support. ${ }^{70}$ For the first time all materials were placed on the open stacks and became readily accessible. There were sufficient staff resources to publish the important annual reference works Index to Canadian Legal Periodical Literature 
and World Wide Space Law Bibliography. ${ }^{71}$ The collection, however, continued to increase at an alarming rate, adding another 50,000 volumes in the ten year period $1965-1975 .{ }^{72}$

\section{Other special collections}

In 1951 the Institute of Air Law (now the Institute of Air and Space Law) was founded at McGill, largely at the initiative of John Cobb Cooper. This was done in cooperation with the UN's International Civil Aviation Organization and the International Air Transport Association, both headquartered in Montreal. One of the world's best collections in the area was developed and this was augmented following Cooper's death in 1967 when his collection came to the library. When John Peters Humphrey retired from the United Nations in 1966, he donated his collection of primary UN materials in the area of human rights. This collection was later found to contain the first manuscript drafts of the Universal Declaration of Human Rights. ${ }^{73}$ The original collection has become less important as these materials are digitized but Humphrey left a major endowment for the purchase of materials in the area of the international law of human rights, and so a strong collection has been maintained. Perhaps most important was the acquisition of the Olivier-Martin collection on early French private law. This is known as the Wainwright Collection as it was purchased and donated to the library by Arnold Wainwright (B.A 1899, BCL 1902). ${ }^{74}$ F.R. Scott, a member of the Royal Commission on Bilingualism and Biculturalism, presented all the manuscript papers associated with the Commission. ${ }^{75}$

\section{A Growing Crisis}

While one might imagine the move to New Chancellor Day Hall would have been the beginning of a golden era for Law Library users, this was not the case. Complaints began to come in early on. In 1974, the chair of library users committee wrote to the law librarian concerning structural alterations, stating:

The main problem is noise, a problem which has become severe with the unexpected growth of the student population in the law school, and with the installation of noise-making devices such as Xerox machines.

The main feature of the changes should be the elimination of the center stairwell of the library, which functions as a noisewell to permit the drift of noise from one floor to another. ${ }^{76}$

This suggestion was sent to the highest levels of the University but was not acted upon at this time. Indeed, VicePrincipal S. B. Frost had earlier noted the "necessity of placing as much money as we can into book purchase accounts"?
The thought of spending significant sums on renovating a relatively new building did not appeal at this time.

Since professors found the library unsatisfactory for their research, the Law Reading Room was created in the old mansion with key serial titles so the professoriate would not have to go to the library. A second satellite library, the Faculty Reading Room, was later created across the road in the J.K.L. Ross mansion, where Paul-André Crépeau directed the Civil Code Revision Office. The library itself often held duplicate subscriptions to continuations so the second copy could be routed to interested faculty. This meant that for the major Canadian titles the library often purchased four or even more subscriptions.

Matters grew worse in the 1980s. The cost of labour and materials began spiraling upwards. The emphasis on purchasing multiple copies of continuations obliged the library to begin putting parts of the collection in various storage areas in the two buildings. In 1984 the central staircase was removed and floored over, not because it was a 'noisewell' but in the desperate search for more space. The alteration had a negative effect in terms of lighting and, especially, ventilation. The library became an unpleasant place to work. Security also became a major problem. The library had a key-operated staff elevator that allowed faculty to come and go without passing the service desk and security gates. Inevitably, almost every student obtained a copy of the key and losses began to mount. By June, 1988 over $90 \%$ of the following year's serial budget had been taken up in previous over-expenditures. The Faculty had begun to emphasize scholarly publication over black letter law, which required a much greater collection of scholarly monographs for which the library had no funds. The library as it operated was no longer sustainable and difficult changes had to be made.

The 1990s saw dramatic changes in the services offered by the Law Library. Many of these changes removed privileges that the Faculty had long enjoyed. Duplicate subscriptions were cancelled, which meant the two satellite libraries were not kept up to date and periodicals were not longer routed to faculty. ${ }^{78}$ Titles in the library but available elsewhere at McGill were also cancelled and, eventually, unique but little used titles were also dropped. The staff elevator was rekeyed, but keys were not issued to professors. Technical services were centralized once more with the main library, and staff transferred with the work. Law had remained aloof from the central system's automation project for somewhat unusual reasons. ${ }^{79}$ This view changed and the collection was barcoded and its records converted to machine readable form. This allowed the first proper inventory for many years, while introducing the automated acquisitions, cataloguing and circulation systems.

Despite the difficulties many of these decisions caused, there were also brighter sides. The Library took a lead role in the development of a local area network for the Faculty, 
which provided email and word-processing facilities to everyone's desktop. ${ }^{80}$ As more and more resources appeared in electronic form, these materials were also delivered lessening the pressure on print resources. Most important of all, the faculty was taking important steps. Discussions were initiated to replace the National Programme, where the second degree was optional, with a Trans-systemic Program, where civil and common law concepts were taught in the same class and students would be obliged to take both degrees. It was felt that this unique curricular departure would require, amongst many other things, a first class research library. The building of a new library became the only faculty goal for the capital campaign. It became apparent early on this goal would not have support from either University ${ }^{81}$ or government funding, so would have to be financed entirely from private donations. Every professor donated to the project, along with law firms and many alumni. When the principal donor Nahum Gelber (BA 1954, BCL 1957), for whom the library would be named, made his contribution the project became a reality.

\section{The Nahum Gelber Law Library}

The new library opened in 1998, just as the Trans-Systemic Program was starting. It was an extremely pleasant place to study with a great deal of natural light and inspiring art work. There were seminar and moot rooms, as well as an electronic classroom. The classroom became very important for the teaching of legal research and methodology since the preponderance of legal resources were now in electronic form. Every user space was wired for electricity and internet access as it was expected nearly all students would soon have laptop computers. ${ }^{82}$ Old and rare books were stored for the first time in a climate controlled room. The amount of shelving in the new library was about the same as the old one, but the move allowed for the discard of many unnecessary duplicate runs. Furthermore the compact shelving in the basement was user accessible. Campus-wide subscriptions to major databases as well as legal databases available freely on the internet allowed the cancellation of all but core journal and case report titles. The library was therefore free to concentrate on building up a monograph based research collection. By 2003 over half the library collection budget was spent on books, and successful application for rattrapage funding allowed significant historic gaps to be filled. The library no longer restricts itself to purchasing only French and English titles, but collects important works in most major languages.

Despite the high indicators of user satisfaction in LIBQUAL surveys, there are complaints about the Gelber Library. When the library was in New Chancellor Day hall students complained about a lack of seating at examination time. Surveys undertaken then indicated there were always over forty seats free. ${ }^{83}$ The same complaint is echoed about the Gelber Library but with much greater reason. Since the Gelber Library is an extremely pleasant study environment, far more so than the old library, students from other faculties come from far and wide to prepare for exams. Seating is hard to find and tensions arise between law and non-law students at this stressful time of year. ${ }^{84}$ Various policies have been employed to alleviate the situation, but with no very great success since all McGill students enjoy equal rights to use all McGill libraries. However, in the last few years, the University library system has made major renovations to a number of libraries, making them far more attractive places to study. Hopefully this will lessen the pressure on the Gelber facility.

\section{Conclusion}

The Faculty of Law, despite placing the highest emphasis on library resources, has not always been well served in this regard. In its first century it had no library and, though the materials were plentiful, they were frequently scattered and all but the core materials were inaccessible. The principal problem was lack of space both in the University Library and in the many locations to which the Faculty moved until it found a seemingly permanent home. Even following the move to the Old and New Chancellor Day Halls, collection building tended to concentrate on primary materials-legislation and court reports-and journal subscriptions. Research collections only existed in a few narrow areas such as air law, old French law, and human rights. As long as the faculty's mission was to teach Quebec civil law in English, library resources were not a major problem. Most courses used the casebook method, which provided students with key readings and was backed up by a strong collection of practitioner manuals for various aspects of Quebec civil law. Furthermore, most faculty research tended to rely on primary legal materials and law journal articles.

This situation changed for a number of reasons. The introduction of the National Programme in 1968 required building collections for common law jurisdictions that had previously not been purchased. In the 1980s, a growing interest in foreign, comparative and international law developed combined with a significant increase in largely foreign graduate student enrollment. Faculty numbers also increased sharply with correspondingly diverse research needs. The curriculum became much broader, especially after the introduction of the Trans-systemic Program in 1999. The library was obliged to alter its collection policy dramatically to adjust to the new user needs. This would not have been possible but for several factors: the Faculty successfully created a state-of-the-art facility through private fundraising; legislation, case law and journals became available electronically either through commercial publishers or free of charge through government initiatives; the integrated library system allowed for the economic centralization of a variety of services, thus allowing reductions in staff; and, the University supplied an excellent technological infrastructure, 
with its associated support. The Law Library was then free to concentrate resources on building a collection supporting legal research in its broadest terms, and on helping users to adjust to the new technologies. This has been achieved to a major extent. Hopefully the user of today will not experience "the inconvenience of the present arrangement" to the extent H.A. Smith did nearly a century earlier.

\section{Acknowledgements}

The author would like to thank Emeritus Professor G. Blaine Baker for his incisive comments on an earlier draft and his useful suggestions for further sources. The help provided by Theresa Rowat and staff in the McGill University Archives, in particular Mary Ellen Houde and Bruce Dolphin, has proved essential. Isabelle Robitaille of the Bibliothèque et Archives nationales du Québec kindly provided information on her researches into the Griffin Collection. As always, my former librarian colleagues in the McGill Library system were obliging in provided bibliographic details from their collections.

\section{ENDNOTES}

${ }^{1}$ Canadian Bar Association. Committee on Legal Research. "Report". Canadian Bar Review, Vol. 34 (1956), at 1013. McGill law professor F.R. Scott chaired the committee.

${ }^{2}$ Recent LIBQUAL surveys show a generally high level of satisfaction with the collection and services.

${ }^{3}$ S.B. Frost, "The Early Days of Law Teaching at McGill." Dalhousie Law Journal, Vol. 9 (1984), at 153. See also S.B. Frost and D.L. Johnston, "Law at McGill: Past, Present and Future,"McGill Law Journal, Vol. 27 (1981), at 31.

${ }^{4}$ An Act to incorporate the Bar of Lower Canada, 1849 (Can.) 12 Vic c. 46. Badgley drafted and piloted this act through the Legislative Assembly. See G. Blaine Baker, "Strategic Benthamism: Rehabilitating United Canada's Bar through Criminal Law Codification, 1847-54", in J. Phillips, R.R. McMurtry, J.T. Saywell, eds., Essays in the History of Canadian Law: A Tribute to Peter N. Oliver (Toronto, University of Toronto Press, 2008), at $257 \mathrm{ff}$. For biographical information on Badgley, see generally Dictionary of Canadian Biography (DCB), vol. XI, 1881-1890, at 40.

${ }^{5}$ The first law students were admitted in September, 1854 after AugustinNorbert Morin was installed as Dean (June 13,1854) and the first three graduates (Robert Alleyn, Charles-Étienne Dallaire and Hammond Gowen) received their LLB degrees in 1856. See Sylvio Normand, Le droit comme discipline universitaire: une histoire de la Faculté de droit de l'Université Laval (Québec: Les presses de l'Université Laval, 2005), at 247.

${ }^{6}$ Principal Charles Dewey Day announced this to the Bar on July 17, 1853.

${ }^{7}$ McGill's first graduates from the Law Faculty received their degrees in 1854.

${ }^{8}$ An Act to declare valid the Articles of Clerkship of Law Students enregistered within a certain period after the delay granted by the Act to incorporate the Bar of Lower Canada, and to amend the said Act, 1853 (Can.) 16 Vic c. 130, s. 6.

${ }^{9}$ Governors' of McGill College Minute Book, 1829-1871., 27 July 1854. McGill University Archives [hereinafter cited as MUA, RG4, cont. 3, File 09003.

${ }^{10}$ For a fuller description of the various premises used by the Faculty, see Ian C. Pilarczyk, A Noble Roster (Montreal: McGill University Faculty of Law, 1999), at $94 \mathrm{ff}$. Pilarczyk gives the University Street address as 746, which may have reflected an earlier numbering.
${ }^{11}$ Space became available when the Faculty of Arts, which had been using Burnside Hall, moved back on campus. See Edgar Andrew Collard, "The High School of Montreal” The Gazette (Montreal), October 4 1943, p. 23.

${ }^{12}$ For the reasons behind this significant change, see A.J. Hobbins, "No longer 'naked and shivering outside her gates': Establishing Law as a Full-time On-campus Academic Discipline at McGill University in the Nineteenth Century." Dalhousie Law Journal, XXXIV (2011), 373-404.

${ }^{13}$ The rationale for giving the Ross Mansion to Law over other claimants is explained in A.J. Hobbins, "'Designating the Dean of Law: attempts to control the nature of legal education at McGill University by the Montreal corporate and professional elite, 1946-1950." Dalhousie Law Journal. XXVII (2004), at 172, note 25 .

${ }^{14}$ Stanley B. Frost, McGill University for the Advancement of Learning. (Montreal: McGill-Queen's University Press, 1980). Vol. I, pp. 247 ff. Molson Hall was later renamed as the West Wing of the Arts building.

${ }^{15}$ Griffin's collection, which covered many subjects beyond law, is currently being analyzed by Isabelle Robitaille of the Bibliothèque et Archives nationales du Québec. See “Frederick Griffin's Library”, Coranto 28 (2011), at 4. Robitaille has not yet analyzed the legal texts but estimates they represent less than $5 \%$ of the collection.

${ }^{16}$ DCB Vol XI, (1881-1890), at 237.

${ }^{17}$ Mackay to William Taylor (assistant in the College Library), May 28, 1885. MUA, RG40, Cont. 2, File 1447 "Mackay Library". This was a covering letter for a donation of books that "will fill up the blanks that ought not to be allowed in the University Library". The file contains many lists of books although it is not clear which books were received during Mackay's lifetime and which came as a bequest.

${ }^{18}$ Peter F. McNally and Christina M. Boyle, "Judge Robert Mackay's 1882 Catalogue of Books: A Preliminary Analysis." Fontanus, vo. X, 1998, at 67. McNally and Boyle analyzed the non-legal titles in the collection based on an 1882 printed catalogue of the collection. The law collection has not been analyzed but, based on the book catalogue, the legal collection has been reconstituted as part of a project organized by McNally and Law Librarian Daniel Boyer. See also G.B. Baker et al., Sources in the Law Library of McGill University for the Reconstruction of a Legal Culture of Quebec, 1760-1890 (Montreal: Faculty of Law and Montreal Business History Project, McGill University, 1987).

${ }^{19}$ Minutes, supra note 9, May $3^{\text {rd }} 1856$ p. 190 . See also Marianne Scott, "An Historical review of the Development of the McGill Law Library, 1848-1975" Draft manuscript, February 1981. "Law" MUA, RG40, Cont. 234, File 1192, at 4. The Advocates' Library and Law Institute of Montreal was established by a group of Montreal Anglophone lawyers and judges in 1828 and available only to members. Following an agreement in 1853, it was managed by the Montreal Section of the Lower Canada Bar to allow greater access to all lawyers. M. Nantel, "The Advocates' Library and the Montreal Bar." Law Library Journal Vol. 27, 1934, at 88 and M. Nantel, "La Bibliothque du Barreau et les archives judiciaires de Montréal." Revue du Barreau Vol. 6, 1946, at 59. In December 2001, the Bar of Montreal transferred its library to CAIJ (Centre d'accès à l'information juridique), an organization associated with the Barreau du Québec and dedicated to developing and modernizing access to all the legal information available, both in print and electronic. See also Gilles Gallichan, "La Bibliothèque du Barreau du Québec: l'emergence d'une institution", Les Cabiers de Droit, Vol. 34, 1993, pp. 125-152. For developments in Ontariro, see A. Rosemary McCormick, "The Libraries of the Law Society of Upper Canada" Law Society of Upper Canada Gazette, Vol. 6, (1972), p. 55 ff.

${ }^{20}$ The full text of Fraser's will is found in the decision of the Judicial Committee of the Privy Council. "The Honourable John J. C. Abbott et alv John Fraser et al” (Canada) [1874] UKPC 72 (26 November 1874), available online at http://www.bailii.org/uk/cases/UKPC/1874/1874_72.html.

${ }^{21}$ Fraser's will was declared valid by Quebec Superior Court in March, 1871. However this decision was overruled in June 1873 by the Court of Queen's Bench (now the Quebec Court of Appeal) in a three-two decision on the basis that a 1743 Edict of Louis XV was still in force. Abbott appealed this decision to the Judicial Committee of the Privy Council in London (then Canada's court of last resort). His appeal was upheld on November 26, 1874 (supra note 20). This should have ended the matter but Fraser's family continued to litigate, attempting to have their brother declared of 
unsound mind and accusing the Institute's governors of various financial improprieties. The matter was not finally ended until 1883. See G.B. Baker, "Law Practice and Statecraft in Mid-Nineteenth Century Montreal: the Torrance-Morris Firm 1848-1868" in C. Wilton, Beyond the Law: Lawyers and Business in Canada 1830 to 1930 (Toronto: Butterworth, 1990), at 45.

${ }^{22}$ Both Abbott and Torrance gained their professional accreditation through articling, but did receive McGill law degrees at a time when both were on the faculty.

${ }^{23}$ Abbott was the first president (1870-1893) and the remainder of the Board had much in common with McGill's Board of Governors. At various times the governors included Sir Donald Smith (later Lord Strathcona), Sir William Macdonald, John H. R. Molson, Peter Redpath and Hugh McLennan, all long serving members of the McGill Board. Torrance also served on the McGill Board from 1870 until his death.

${ }^{24}$ Edgar C. Moodey, The Fraser-Hickson Library: an Informal History (London: Bingley, 1977), at $62 \mathrm{ff}$. The Institut Canadien books remained with the Fraser Institute following the demise of the Institut.

${ }^{25}$ Ibid., at 163.

${ }^{26}$ Governors' and Royal Institution Minute Book, 5 April 1890, p. 468. MUA, RG4, Cont. 5 (1884-1891). See also Hobbins, supra note 12.

${ }^{27}$ Trenholme (B.C.L. 1865) was the first winner of the Elizabeth Torrance Gold Medal for highest standing. He served as Dean (1888-1895) before returning to private practice, and batonnier of the Montreal Bar (1898-1899). He became a Federal QC in 1889, and served as a judge on the Quebec Court of Appeal (1904-1918). See Henry J. Morgan, Canadian Men and Women of the Time (Toronto: Briggs, 1898), at 1,020, and MacMillan Dictionary of Canadian Biography (Toronto: Macmillan, 1963), at 755 .

${ }^{28}$ McGoun, in addition to his duties as Secretary and Librarian, taught a variety of subjects retiring in 1920, a year before his death. He also continued his legal practice, first with F. L. Beique and then with his own firm McGoun and England. He was created KC (Quebec) in 1905. See Morgan, at 738 and MacMillan, at 456, both supra note 27. McGoun was an avid snowshoer and Scottish dancer; he would have his students snowshoe up to his house, high on the mountain, following which they would enjoy dancing. See Pilarczyk, supra note 10, at 73 . For law library developments at Dalhousie University, see Philip Girard, "His whole life was one of continual warfare': John Thomas Bulmer, lawyer, librarian and social reformer," Dalhousie Law Journal (Halifax), 13 (1990): 376-405.

${ }^{29}$ See Moodey, supra note 24 , at 84.

${ }^{30}$ See R.A. Macdonald, "The National Law Programme at McGill: Origins, Establishment, Prospects", Dalhousie Law Journal, XIII (1990), at 243. The author has been unable to verify this commitment which seems remarkably large given the size of both the student body and the Redpath Library.

${ }^{31}$ Ibid., at 242. Macdonald suggests the law reading room was rarely used based on its lack of proximity to the classrooms in the East Wing of the Arts Building. He cites as a source Peter F. McNally, "A Chronology of Events in the History of the Faculty of Law Library", (unpublished manuscript dated March 27, 1975). McNally cannot recall the document but suspects that it may have been part of some correspondence with the then Dean John Brierley. It has not been found and McNally cannot recall the basis for the information.

${ }^{32}$ For a description of Lee's program see A.J. Hobbins, "A couple of generations ahead of popular demand": The First National Law Program at McGill University, 1918-1924.'Dalhousie Law Journal, XXXI (2008). pp. 181-210.

${ }^{33}$ See generally Macdonald, supra note 30 , at 256, note 92. See also Hobbins, supra note 32 , at $196 \mathrm{ff}$.

${ }^{34}$ Smith to Wood, October 12, 1920. "Library" MUA, RG 37, Cont. 1, File 1. The Faculty was then located on University Street.

${ }^{35}$ Wood to Smith, October 17, 1920. Ibid. For biographical information on Wood (1856-1942) see Canadian Medical Association Journal, vol. 46, 1942, at 297.

${ }^{36}$ Lomer to Smith, November 9, 1920. Ibid.
${ }^{37}$ Special Library Committee. Memorandum of Proposed Changes. March 10, 1921. Ibid.

${ }^{38} \mathrm{Ibid}$.

${ }^{39}$ Lomer to Smith, June 4, 1923. Ibid.

${ }^{40}$ Smith to Librarian, Montreal Court House, September 28 1923. Ibid.

${ }^{41}$ See Scott, supra note 19, at 2.

${ }^{42}$ For biographical information on Corbett, see A.J. Hobbins, "Mentor and Protégé: Percy Corbett's relationship with John Peters Humphrey." Canadian Yearbook of International Law, 1999. XXXVII (2000), pp. 3-56.

${ }^{43}$ Lomer to Corbett, February 10, 1927 MUA, supra note 34.

${ }^{44} \mathrm{Ibid}$.

${ }^{45}$ Secretary of the Board to LeMesurier, April 5, 1927. Ibid.

46"Library", supra note 34. The Principal then lived in the former Baumgarten House at 3450 McTavish St., now the Faculty Club. Scott, supra note 19 , reported that during this time, in addition to the stable, the boxes were stored in the Biology Building (now the James Administration Building), Molson House and Macdonald College. Although there were several Molson Houses near the University, they were not owned by the University. It is more likely Scott was referring to the original Molson Hall, now the West Wing of the Arts Building, which had housed the original University book collection before Redpath Library was constructed.

${ }^{47}$ Buchanan to Corbett, April 15 1935. "Library", MUA RG37, Cont. 1, File 2. Although Buchanan graduated from law before Corbett came to the faculty, it is evident from the salutation "Dear Corby" they knew each other well. They both served in the $13^{\text {th }}$ Battalion (Royal Highlanders of Canada) CEF during the First World War and very likely became acquainted then. The original Macdonald Engineering Building was attached to the Workman Workshops in 1893. Both were rebuilt following the fire in 1907. The McGill contingent of the COTC had taken over 3484 University Street, after the Faculty left the mansion in 1923. McGill News, Vol. 21 (Autumn, 1939), at 8. Possibly the law books had been in this building since the Faculty left a decade before. After the COTC removed to the new Armory in 1941, the mansion became the war-time headquarters of the International Labour Organization. The School of Architecture moved there in 1947, describing the building as a "rambling, neo-medieval mansion with turrets, secret nooks and crannies, and a picturesque but complex roof." Norbert Schoenauer, "McGill's School of Architecture: a Retrospection", in McGill University. School of Architecture and Urban Planning. Prospectus (Montreal: School of Architecture and Urban Planning, 1987), at 17. The building was demolished in 1958 when the McConnell Engineering Building was constructed. Ibid., at 23.

${ }^{48}$ DCB Vol XV (1921-1930), at 607. Lafleur's parents were of Swiss descent and his father, Theodore Lafleur, was a Baptist Minister. Lafleur later joined the Church of England. See also D.R. Williams, Just Lawyers: Seven Portraits. (Toronto: University of Toronto Press for the Osgoode Society for Canadian Legal History, 1995).

${ }^{49}$ De Crèvecouer to Lomer Nov 29 1929. MUA, supra note 47. John Fair (1857-1947) was a local notary who served as the Institute's president (1933-1939). Joseph William Andrew Hickson (1873-1956), a McGill philosophy and psychology professor, as well as a noted mountaineer, was also later president (1939-1945). Hickson left his estate of nearly two million dollars to the Institute provided his name was added to its title. Moodey, supra note 24, at 162.

${ }^{50}$ Lomer to LeMesurier, December 18, 1929. Ibid

${ }^{51}$ Lafleur to LeMesurier December 26 1929. Ibid.

${ }^{52}$ Moodey, supra note 24 , at 128 .

${ }^{53} \mathrm{H}$. Larratt 'Laddie' Smith to LeMesurier, January 30, 1930. MUA, supra note 47.

${ }^{54}$ Moodey, supra note 24 , at 128 .

${ }^{55} \mathrm{Ibid}$.

${ }^{56}$ Lomer to Scott, October 25, 1938. "Library” MUA RG37, Cont. 1, File 3.

${ }^{57} \mathrm{Scott}$ to Lomer, October 26, 1938. Ibid.

${ }^{58} \mathrm{Scott}$ to McDougall, October 31, 1938. Ibid. 
${ }^{59}$ Moodey, supra note 24 , at 129.

${ }^{60}$ Scott to McDougall, December 23, 1938. MUA, supra note 56.

${ }^{61}$ McDougall to Scott, Febraury 13, 1939. Ibid.

${ }^{62}$ Lomer to Fair, February 24, 1939. Ibid.

${ }^{63}$ Moodey, supra note 24, at 165 .

${ }^{64}$ Ibid., at 166 .

${ }^{65}$ Scott, supra note 19 , at 5 . The Fraser Institute stayed temporarily in Morrice Hall until the building in NDG was ready. Morrice Hall belonged to the Presbyterian College until J.W. McConnell purchased it in 1961 and donated it to the University.

${ }^{66}$ See Virtual McGill at http://cac.mcgill.ca/campus/buildings/Purvis_ Hall.html.

${ }^{67} \mathrm{Scott}$, supra note 19 , at 8 .

${ }^{68}$ McGill University. Annual Report, 1949-1950. at 41.

${ }^{69} \mathrm{Scott}$, supra note 19 , at 8 .

${ }^{70}$ The National Programme allowed students to take either a civil or common law degree and, after studying an extra year, could obtain both. Currie's assessment that Lee's 1918 national program was a "couple of generations ahead of popular demand" proved remarkably accurate. See A.J. Hobbins, supra note 32.

${ }^{71}$ The Index, founded in 1963 by Law Librarian Marianne Scott, was created by staff members Gabor Both and Arnold Banfill. The Bibliography was authored by Head of Public Services Kuo-Lee Li.

${ }^{72} \mathrm{Scott}$, supra note 19 , at 12 .

${ }^{73}$ These drafts along with other Humphrey papers were given to the McGill University Archives in 1989 (MUA, MG 4127). See A.J. Hobbins, "René Cassin and the Daughter of Time: the First Draft of the Universal Declaration of Human Rights". Fontanus II (1989) pp. 7-26.
${ }^{74}$ For the story behind the acquisition of the Wainwright Collection, see M.L. Renshawe and J.E.C. Brierley, "Sources in Civil Law: the Wainwright Collection" Fontanus, vol. I, 1988, at $77 \mathrm{ff}$. See also M. Scott, "The Wainwright Collection", McGill Law Journal,Vol. 8, 1961, at $57 \mathrm{ff}$.

${ }^{75}$ Scott to Keith Crouch (Director of Libraries) April 11, 1972. MUA, RG 40, Cont. 160, File 207. These papers have since been given to McGill University Archives (MUA MG 2004).

${ }^{76} \mathrm{HP}$ Glenn to Marianne Scott, May 2 1974. Memorandum on "structural changes to the Law Library". "AL Law, 1973-1974" MUA, RG40, Cont. 160 , file 209.

${ }^{77}$ S.B. Frost to H.P. Glenn, December 19, 1973. Ibid.

${ }^{78}$ For a while tables of contents of journals and case reports were photocopied and sent to professors, but this labour-intensive activity was also dropped after a few years.

${ }^{79}$ It was perceived that if Law's holding were not in the online catalogue this would lessen the pressure on the library, while law users would have the advantage of knowing the holdings of all other McGill libraries. This viewpoint overlooked the huge advantages of automation that went far beyond the online catalogue.

${ }^{80}$ The Library staff continued in this role until 2003, when local area networks gave way to campus-wide ones and technical support was centralized.

${ }^{81}$ The University did make a loan of $\$ 900,000$ so construction could start. Some eight years later this debt was forgiven so the University became a delayed contributor to the project.

${ }^{82}$ Unfortunately the introduction of wireless technology could not be predicted. The hard-wired internet jacks are hardly used and, even from the first, only half of them were activated at the server end.

${ }^{83}$ Scott to Glenn, February 21 1974, at 1. MUA, supra note 76.

${ }^{84} \mathrm{Law}$ students use the acronym SNAILS (students not actually in law) to refer to non-law users. 